\title{
Editorial Editorial
}

GALILEU - REVISTA DE DIREITO E ECONOMIA - e-ISSN 2184-1845

Volume XX $\cdot 1^{\text {st }}$ January Janeiro $-30^{\text {TH }}$ June Junho $2019 \cdot$ pp. 6

No ensejo de afiançar a continuidade da divulgação da produção cientifico-jurídica apresenta-se este novo volume da Revista Galileu onde se recolheram diversos textos de relevo dentro das respetivas áreas temáticas. Os trabalhos ora apresentados resultaram da investigação dedicada e criteriosa de docentes universitários e doutorandos nacionais e internacionais que, desta forma, concretizaram um magnífico contributo para o desenvolvimento do estado da arte nas suas correspondentes áreas do saber jurídico.

Muito nos congratulamos com o grande número de textos rececionados para publicação, mas infelizmente, as normais limitações de uma publicação desta natureza obrigam a tomada de decisões no sentido de selecionar os textos mais pertinentes e atuais, quer pela sua temática, quer pela sua concreta abordagem, o que em nada desmerece aqueles outros textos que não puderam ver a luz nesta publicação.

Não seria justo concluir este editorial sem agradecer a dedicação e empenho de toda a equipa do Centro de Investigação Ratio Legis, o apoio do Departamento de Direito da Universidade Autónoma de Lisboa e a disponibilidade e suporte constantes da Cooperativa de Ensino Universitário que com os seus contributos, fazem possível a continuação da nossa missão.

Assim, esperamos que os textos ora apresentados, cumpram as expetativas do mais exigente leitor, pois tal é o propósito que abraçamos.

O Diretor da Galileu

Ruben Bahamonde Delgado 